\title{
Vybrané otázky československých amnestií trestněprávních deliktů ve 20 . a 30. letech 20 . století ve vztahu k národnostním menšinám
}

\author{
Jiř́ Šouša
}

Ústav právních dějin, Právnická fakulta, Univerzita Karlova

Kontaktni e-mail:sousaj@prf.cuni.cz

Selected Aspects of Czechoslovakian Amnesties of Crimes in the 1920s and 1930s in Relation to National Minorities

\begin{abstract}
:
The article deals with the amnesties of criminal offenses in the 1920s and 1930s in Czechoslovakia, which were related to the minority issue. First of all, it seeks to categorize and analyse common features, legal contexts and provides a brief analysis. This is a topic that interferes with the history of the constitutional, criminal, and administrative law sector. The article shows the growing importance of minority issues both in court trials of felonies and in the announcement of amnesty in the second half of the 1930s. The article also highlights the importance of international influences on the development of these amnesties. It considers that the amnesties that did not remove the harshness of the law, but only corrected the judicial decisions, were in the end ultimately counterproductive. Finally, the article intends to explore the possibilities for further research in this area.
\end{abstract}

\section{Keywords:}

law; minorities; amnesty; history; Czechoslovakia; Germans

\section{Klíčová slova:}

právo; menšiny; amnestie; historie; Československo; Němci

DOI: $10.14712 / 2464689 X .2018 .25$

Financování: Tento článek byl vypracován v rámci programu PROGRES Q04. Právo $\mathrm{v}$ měnícím se světě. 
Článek se věnuje československým amnestiím trestněprávních deliktů ve 20. a 30. letech 20. století ve vztahu k menšinové otázce. Předně usiluje o jejich kategorizaci a analýzu společných znaků, právních souvislostí a podává jejich stručný rozbor. Jedná se tedy o tématiku, jež zasahuje do dějin odvětví práva ústavního, trestního, i správního.

Vojtěch Zamarovský napsal ve svých Dějinách psaných Římem, že historie je (in eventum má být, pozn. autora) dialogem mezi minulostí a současností. ${ }^{1}$ Právě př́tomnost představuje éru, která badatele př́mo podněcuje k takovému výzkumu. Menšinová otázka a její juristická stránka se totiž, s ohledem na multikulturní charakter převážné většiny států euroatlantického prostoru a rovněž na proběhnuvší či probíhající imigrační a exulantské vlny poslední doby, ${ }^{2}$ stává jedním z aktuálních významných nejen politických, ale stále více i právních témat, a to nejen v České republice. ${ }^{3}$

Zároveň se však do popředí diskuzí ve veřejném prostoru (do nichž se zapojuje i jurisprudence) dostává otázka práva milosti v širším slova smyslu, resp. možnost změny jeho zařazení v rámci systému dělby moci, eventuálně jeho přenosu v rámci působnosti ústavních orgánů. Děje se tak především v souvislosti s tzv. sporem o amnestii, tj. diskuzemi ohledně povahy, účelnosti a dopadů amnestií vyhlášených po roce $1990 .{ }^{4}$ Tehdy se následkem amnestií Václava Havla a Václava Klause ve veřejnosti (opět inklusive té veřejné) rozšiŕil v nemalé míře kritický pohled na tuto kompetenci hlavy státu, která bývá někdy označována jako pozůstatek feudálních prerogativ. Spor o amnestii pak logicky přinesl rovněž úvahy o změnách $\mathrm{v}$ působnosti ústavních institucí a činitelů v tomto směru a dokonce do jisté míry vedl k relativizování vhodnosti a potřebnosti jejího dalšího uplatňování. Přitom, jak napsal Marcus Tullius Cicero: Historia vero testis temporum, lux veritatis, vita memoriae, magistra vitae, nuntia vetustatis, qua voce alia nisi oratoris immortalitati commendatur? ${ }^{5}$ A právě zkušenost z minulosti, této učitelky života, ukazuje, že se právní instituty častované adjektivy ve smyslu ,zastaralé, přežilé, nefunkční, zbyteč-

1 ZAMAROVSKÝ, V. Dějiny psané Řimem. Praha: Garamond, 2015, s. 7.

2 Viz azylové statistiky eurostatu, dostupné online dne 30. 1. 2018 na http://ec.europa.eu/eurostat/statistics -explained/index.php/Asylum_statistics. Podle Rady pro lidská práva OSN (UNHRC) byla zatím nejzávažnější situace v roce 2015, kdy jen po moři dorazilo 1.015.078 imigrantů. Viz infografika UNHRC, dostupná online dne 30. 1. 2018 na http://data2.unhcr.org/en/situations/mediterranean. Přestože imigrace podle uvedených statistik významně poklesla, byl navržen tzv. Dublin IV., tj. další novelizace Dublinských dohod (poslední nařízení Evropského parlamentu a Rady Evropské unie č. 604/2013 ze dne 26. června 2013).

3 Viz k tomu podrobněji např. mezinárodní publikace ŠUTAJ, Š. - REGINÁČOVÁ, R. - HELDÁKOVÁ, L. (eds.). Aktuálné otázky výzkumu národnostnej politiky a národnostních vzt'ahov. Prešov: Universum, 2017. K aktuálním otázkám problematiky výzkumu právní úpravy postavení menšin na území České republiky viz PETRÁŠ, R. - KUKLÍK, J. Aktuální problémy výzkumu právního postavení menšin v České republice. In: Tamtéž, s. 129-139.

4 Toto označení vědeckého i celospolečenského diskurzu ohledně zachování právního institutu amnestie v českém právním řádu, resp. změny pravomoci a působnosti k jeho uplatňování, je převzato z názvu publikace Kol. autorů: Spor o amnestii. Praha: Institut Václava Klause a Centrum pro ekonomiku a politiku, 2013. Vedle sporu o amnestii podněcují diskurz i individuální akty doby nedávné. Např. ve čtvrtek dne 22. 6. 2017 se uskutečnil v prostorách ústavněprávního výboru Poslanecké sněmovny PČR reprezentativní vědecký seminář na téma „Milost prezidenta republiky - Mimořádný institut k odstranění tvrdosti zákona nebo pouhý politický nástroj?“ za účasti významných osobností právní vědy i právní praxe. Diskutovány nebyly jen otázky milostí v užším slova smyslu, nýbrž právě i amnestie.

5 CICERO, M. T. De Oratore. Für den Schulgebrauch erklärt von Karl Wilhelm Piderit. Leipzig: B. G. Teubner, 1862, s. 110. V elektronické podobě dostupný online dne 2. 2. 2018 na https://ia802707.us.archive.org /27/items/deoratore00pidegoog/deoratore00pidegoog.pdf. 
né, neodpovídající duchu doby“ časem mohou ukázat jako pravý opak těchto přívlastků, tj. naopak za použitelné. Proto je užitečné ukázat historické souvislosti problematiky. ${ }^{6}$

Jestliže se dnes oba tyto právní instituty (tj. otázka národnostní a amnestijní) v České republice prozatím neprotínají, což platí i ohledně výzkumu této problematiky, je třeba říci, že i ve zkoumaném období v prvních letech svrchovaného státu amnestie menšinovou otázku obvykle neodrážely. To se však brzy změnilo s tím, jak byla věc československých menšin umně použita sousedními státy, ale i skutečností, že se samotným aktérem mezinárodních vztahů sui generis začali v letech 1920-1930 v důsledku svých aktivit stávat čeští Němci. Ti komunikovali nejen s konzervativními kruhy Spojeného království Velké Británie a Severního Irska, ale zejména podali celkem 24 petic Společnosti národů, jež upozorňovaly na údajnou diskriminaci německé menšiny v ČSR. ${ }^{7}$ Amnestie, především ty, jež se týkaly politických deliktů, ${ }^{8}$ pak jako nástroj trestní politiky mohly být použity ke zmírnění vnitrostátního i mezinárodního napětí. Tak bývají ostatně amnestie používány při konfliktech s nacionálními minoritami dodnes. ${ }^{9}$ Proto je zde nutné též vnímat hledisko užitečnosti zkoumání amnestijní problematiky v souvislosti s menšinovou otázkou pro aplikační praxi, nebot' jde o prezentní nástroj trestní a ústavní politiky. Z hlediska budoucího zkoumání a zejména aplikační praxe, je použití koncepce dialogu mezi minulostí a současností přínosné, v př́ípadě, je-li to možné, např. když právněhistorický institut je nástrojem platného práva. Zároveň však je poznanou nutností, aby badatel nesklouzl k prezentismu. Prezentismus je terminus technicus, jež označuje reflexi současných př́stupů a pohledů do minulosti, a to bez ohledu na fakta a akcent na dobový rámec.

\section{Amnestie ve vztahu $k$ menšinové problematice v letech 1918-1920}

Je nesporným faktem, že menšinová problematika, zvláště pak ta nacionální, hrála v meziválečné mnohonárodnostní Československé republice signifikantní roli s ohledem na práva a svobody 1. a 2. generace, které chtěl svým občanům nový stát poskytnout, stejně jako vzhledem ke koncepci ochrany tzv. kolektivních práv prŕislušníků menšin. Tato koncepce se prosazovala přes mezinárodní organizace a fóra. $\mathrm{K}$ jejich zakotvení v právním řádu se ve vztahu k menšinám zavázalo (nejen) Československo v mezinárodních smlouvách a posléze byly, s ohledem na tehdejší dualismus mezinárodního a vnitrostátního práva, ${ }^{10}$ inkorpo-

6 PAVLÍČEK, V. O české státnosti. Úvahy a polemiky. 2. O právech, svobodách a demokracii. Praha: Karolinum, 2002, s. 176.

7 Viz např. PITRONOVÁ, A. Čeští Němci jako svébytný prvek mezinárodnich vztahů. Brno, 2010. Bakalár̆ská práce. Masarykova univerzita, Fakulta sociálních studií, s. 14.

8 Podrobněji např. viz ŠOUŠA, J. Amnestie politických deliktů v době 1. Československé republiky. In: Paginae Historiae. Roč. 24. č. 2. Praha: Národní archiv, 2016, s. 42-69, nebo SUCHOMEL, V. Komparace průběhu soudnich procesů prvni Československé republiky ve světle zákona č. 50/1923 Sb. z. a n. na ochranu republiky. Brno, 2015. Diplomová práce. Masarykova univerzita.

9 Např. v roce 2001 makedonský prezident diskutoval se svými koaličními partnery dílčí amnestii pro albánské separatisty, kteři proti státu vystoupili se zbraní v ruce, pod podmínkou, že složí a odevzdají zbraně a s výjimkou jejich vůdců a těch, kteří mají na svědomí smrt policistů a vojáků. Viz zpráva BBC ze dne 3. 6. 2001 dostupná v elektronické podobě dne 1. 2. 2018 na http://news.bbc.co.uk/2/hi/europe/1367352.stm.

10 Tento dualismus ovšem nebyl úplný. Viz TOMÁŠEK, M. Podíl čs. práva a diplomacie na fungování meziválečné Evropy a formování evropských integračních uskupení. In: MALÝ, K. - SOUKUP, L. Československé právo a právní věda v meziválečném obdobi (1918-1938) a jejich misto ve středni Evropě. 1. vyd. Praha: Karolinum, 2010, s. 366-370. 
rovány do vnitrostátního právního řádu jednak v Ústavní listině 1920, jednak v jazykovém zákoně (ústavní zákon č. 122/1920 Sb. z. a n.) a rovněž v řadě dalších právních předpisů. ${ }^{11}$

Při vzniku Československa, at' už se za datum vzniku považoval ve shodě s T. G. Masarykem 14. říjen 1918 nebo zákonem jako státní svátek, snad náhodou, snad úmyslně o rok později právě také dne 14. ř́ijna, ovšem roku 1919, zakotvený 28 . ř́ijen $1918,{ }^{12}$ kdy byl vyhlášen tzv. recepční zákon, byl akcent vưči menšinám soustředěn na ně spíše jako na pasivní recipienty norem, vytvářených revolučním zastupitelským tělesem, ${ }^{13}$ které nebylo ještě obsazeno volbou a které reprezentovalo svým personálním složením v daném okamžiku pouze dvě větve jediného československého státoprávního národa - Čechy a Slováky. ${ }^{14}$

Pokud se amnestie v prvním období suverénního československého státu, tzn. do přijetí stabilní ústavy v roce $1920,{ }^{15}$ věnovaly nacionální otázce, šlo, s jedinou výjimkou, o nápravu křivd, ${ }^{16}$ spáchaných na českém a slovenském národě rakouskou a uherskou trestní a vojenskou trestní justicí a administrativou, tj. preterování Čechů a Slováků, kteří usilovali o samostatný stát nebo byli představiteli uvědomělého češství. Amnestie soudních deliktů z období 1918-1919 se snažily takové, at' již skutečné anebo domnělé křivdy napravit. Můžeme proto hovořit o amnestiích týkajících se otázky nacionální, nikoliv však otázky menšinové. Takto byla koncipována jak amnestie Národního výboru, vyhlášená nařízením Národního výboru č. 28/1918 Sb. z. a n., o amnestii, ${ }^{17}$ tak následující amnestie. Zmíněn může být i zákon Národního výboru č. 8/1918 Sb. z. a n., jímž se zrušuje zabavení jmění pro činy velezrádné. Zákon rušil ta soudní rozhodnutí, jimiž byl na základě císařského nařízení č. 156/1915 ř. z. v českých zemích, a po novele č. 621/1919 Sb. z. a n. i na základě zákonného článku č. XVIII/1915 na Slovensku a v Podkarpatské Rusi, zabaven

11 Např. v minoritní Saint Germainské smlouvě - Smlouvě mezi čelnými mocnostmi spojenými i sdruženými a Československem, podepsaná v Saint- Germain-en-Laye dne 10. září 1919, inkorporována do vnitrostátního právního řádu pod č. 508/1921 Sb. z. a n., v řadě bilaterálních smluv s vybranými státy či jednostranných prohlášeních států podle systému postaveného na Paktu společnosti národů, tj. Úmluvě o společnosti národů, publikované ve Sbírce zákonů a nařízení pod č. 507/1921 Sb. z. a n. Podrobněji viz PETRÁŠ, R. Menšiny v meziválečném Československu. Právní postaveni národnostních menšin v prvni Československé republice a jejich mezinárodněprávní ochrana. Praha: Karolinum, 2009.

12 Stalo se tak zákonem č. 515/1919 Sb. z. a n., jímž se prohlašuje 28. říjen za svátek státní. Dnes tento státní svátek upravuje $\S 1$ zákona č. 245/2000 Sb., o státních svátcích, o ostatních svátcích, o významných dnech a o dnech pracovního klidu.

13 Nejprve Národním výborem a posléze Revolučním Národním shromážděním.

14 PETRÁS̆, R. The Revolutionary National Assembly in Czechoslovakia 1918-1920. Contentious Issues. In: ADLGASSER, F. - MALÍNSKÁ, J. - RUMPLER, H. - VELEK, L. Hohes Haus!: 150 Jahre moderner Parlamentarismus in Österreich, Böhmen, der Tschechoslowakei und der Republik Tschechien im mitteleuropäischen Kontext. Wien: Verlag der Österreichischen Akademie der Wissenschaften Austrian Academy of Sciences Press, 2015, s. 215-225, a příspěvek téhož na konferenci z 7.-8. dubna 2011 Revoluční národní shromáždění 1918-1920. Sporné právní aspekty.

15 Ústavní listina 1920 uvozená ústavním zákonem č. 121/1920 Sb. z. a n.

16 Cyril Horáček ve svých pamětech píše o „snaze po nápravě“. HORÁČEK, C. Vzpomínky z mého života. Praha: Masarykův ústav a Archiv AV ČR, 2017, s. 213.

17 Přestože právní předpis, zveřejněný v částce IV., publikované dne 9. listopadu 1918 na s. 19 Sbírky zákonů a nařízení, je označen jako nařizení, byl na schůzi Národního výboru, konané dne 5. listopadu 1918 v Grégrově sále Obecního domu, na níž byl schválen, projednáván pod označením zákon o udělení amnestie. Viz stenoprotokol ze schůze Národního výboru ze dne 5. listopadu 1918, v elektronické podobě dostupný dne 7. 8. 2017 na http://www.psp.cz/eknih/1918nvc/stenprot/19181105/19181105_03.htm. Tato změna neznačila jen terminologický posun. Odrážela obtíže ohledně koncepčního uchopení amnestijního aktu z hlediska separace mocí. 
majetek osob odsouzených pro velezrádné činy (tj. politické delikty). Amnestie se nevztahovala na trestné činy spáchané ze ziskuchtivosti. Naposledy k diskuzím v tomto směru došlo v souvislosti s amnestijním rozhodnutím prezidenta republiky ze dne 21. ř́ijna 1919. Uvedená poslední diskuze o odčinění národnostních křivd proběhla v údobí od listopadu 1919 do února roku 1920. Z opakujících se podnětů prezidia ministerské rady (tj. vlády), konkrétně př́ípisu č. 20139/19 ze dne 21. ř́jjna 1919, př́ípisu č. 25992/19 ze dne 6. prosince 1919 a č. $28222 / 19$ ze dne 31. prosince $1919,{ }^{18}$ byla řešena otázka př́padné amnestie disciplinárních deliktů státních úruedníků. Uvedená diskuze rovněž ukazuje ještě nevyřešené kompetenční zařazení administrativních amnestií, k němuž došlo postupně až ve 20 . letech 20. století.

K otázce oné disciplinární amnestie „křivd“ se vyjadřovaly různé ústřední úřady, jež za tím účelem provedly i vnitřní šetření. Některé (nap̌r. ministerstvo zahraničních věcí, ${ }^{19}$ nebo ministerstvo zemědělství) tvrdily, že v oblasti jejich působnosti se žádný prŕípad takové národní křivdy nevyskytuje anebo že ty, jež se odehrály, již byly napraveny. Jiné ústřední úřrady (např. ministerstvo veřejných prací ${ }^{20}$ ) se přiklonily $\mathrm{k}$ řešení problému správní cestou s tím, že kvůli tomu nemusí být vydáván zvláštní amnestijní zákon či obecně závazný normativní akt prezidenta republiky. Svrchu řečený administrativní postup, kdy na některých ministerstvech byla křivda napravena přiznáním služebních požitků v plné výši anebo zlepšením služebního postavení dotčených osob, ovšem balancoval na hraně zákona, konkrétně byl v rozporu s ustanovením $§ 37$ zákona č. 15/1914 ř. z., tj. služební pragmatiky, nebot' zasahoval do zásady ochrany nabytých práv třetích osob, které byly v dobré víře. ${ }^{21}$ Konkrétně těmito nabytými právy byla práva úředníků, kteří byli takovým postupem přeskočeni. ${ }^{22}$

Každá zásada má ovšem své výjimky, a tak v tomto prvním období bylo výjimkou z uvedeného principu monopolu amnestijní nápravy křivd v oblasti amnestií dotýkajících se nacionální problematiky, rozhodnutí prezidenta republiky ze dne 22. července 1919 , kterým prezident nařídil, aby proti osobám s domovským právem v obci Československé republiky, které po 28. ř́ijnu roku 1918 vstoupily do říšskoněmecké či rakouské vojenské formace, nebylo za účast v cizích ozbrojených silách ${ }^{23}$ zahájeno trestní řizení, pokud nebyly tyto osoby trestnými z jiných deliktů a vystoupily do 1. září roku 1919 z rrískoněmeckých a rakouských ozbrojených formací. Uvedená lhůta byla prezidentem Masarykem opakovaně prodloužena, a to na žádost rakouského plnomocníka, nejprve do 15. záŕí,

18 Viz Národní archiv, fond 1082 Předsednictvo ministerské rady 1918-1945, inv. č. 2170, sign. 156-159/1-7 karton 1587, př́ípis MV nazvaný Amnestie úřednictva a odčinění za národní příkoří.

19 Viz NA, 1082 Předsednictvo ministerské rady 1918-1945, inv. č. 2170, sign. 156-159/1-7 karton 1587, Stanovisko MZV ze dne 10. února 1920.

20 Viz NA, 1082 Předsednictvo ministerské rady 1918-1945, inv. č. 2170, sign. 156-159/1-7 karton 1587, Stanovisko MVP ze dne 9. února 1920.

21 Tato zásada má v současnosti dokonce ústavněprávní sílu, když je zakotvena např. v čl. 11 odst. 1 Listiny základních práv a svobod, a její ochranu opakovaně konstatoval Ústavní soud (viz např̀. nález Ústavního soudu ze dne 17. dubna 2014, sp. zn. I. ÚS 2219/2012).

22 Viz NA, 1082 Předsednictvo ministerské rady 1918-1945, inv. č. 2170, sign. 156-159/1-7 karton 1587, Stanovisko ministerstva financí.

23 Viz Archiv Kanceláře prezidenta republiky, KPR, Protokol P, sign. P III 1013/22, nezpracováno, rozhodnutí prezidenta republiky ze dne 22. července 1919. 
posléze do 1 . listopadu $1919,{ }^{24}$ posléze ještě do 1 . dubna roku 1920 a konečně na návrh ministra spravedlnosti do 15 . května roku $1920 .{ }^{25}$

Cílem byla amnestie především českých Němců, pokud pokračovali ve službě v cizích vojenských formacích i po vzniku samostatného státu. Jednalo se v prvé řadě o tzv. Volkswehr a Sudetoněmecké bataliony. Bylo-li svrchu řečeno, že v Národním výboru ani v Revolučním Národním shromáždění nebyli představitelé českých Němců zastoupeni, je vhodné podotknout, že se tak nestalo tolik vinou československé politické reprezentace, ${ }^{26}$ která přes některá nepř́liš št’astná verbální vyjádření, ${ }^{27}$ ve skutečnosti se součinností se zástupci (nejen) německé menšiny počítala, dokonce Antonín Švehla pozval Rudolfa Lodgmana von Auen k účasti v Národním výboru, což tento odmítl. ${ }^{28}$ Spíše šlo o důsledek tehdejší př̀evažující negativistické politiky politických představitelů českých Němců. Již dne 21. ř́jna roku 1918 se setkali ve Vídni němečtí poslanci z Rakouska a českých zemí a vytvořili Prozatímní Národní shromáždění Německého Rakouska, 20členný výkonný výbor (Státní radu), pověřence Státní rady (vládu) a úřad kancléře. ${ }^{29}$

Zatímco do té doby stála německá nacionální reprezentace Rakousko-Uherska pevně na pozicích centralismu, který byl vytčen např. ve Stanovisku Německého nacionálního svazu z března 1916, přihlásila se tímto okamžikem náhle k právu národů na sebeurčení. Logickým důsledkem bylo ustavení čtyř provincií na území Československa, ${ }^{30}$ které se přihlásily k Německému Rakousku a byly v něj (společně s Brnem, Jihlavou a Olomoucí označovanými jako „německé oblasti osídlení“) vtěleny zákonem č. 40/1918 StGbl., o obvodu, ${ }^{31}$ hranicích a vztazích státního obvodu Německého Rakouska. ${ }^{32}$

Tyto územní celky si vytvořily tzv. Volkswehr, tzn. polovojenské ozbrojené jednotky českých i říšských Němců, které byly vytvořeny za účelem boje za připojení pohraničních oblastí k Německému Rakousku. ${ }^{33}$ Tyto jednotky dosáhly počtu cca 10000 osob, byly vyzbrojeny nejen ručními zbraněmi, ale rovněž i kulomety a děly, a dostávaly stravu a cca 10,- K denně jako žold. ${ }^{34}$ Vzhledem k rychlému obsazení pohraničí československou brannou mocí a pod vlivem hrozby, že by části Německa mohly být obsazeny jednotkami

24 Viz Vojenský historický archiv, Vojenská kancelář prezidenta republiky I. 1919-1939, Všeobecná registratura, č. j. 1364, karton 13 Prodloužení lhůty k vystoupení čs. občanů z řŕšskoněmecké nebo rakouské armády 1919.

25 Archiv Kanceláře prezidenta republiky, KPR, Protokol P, sign. P III 1013/22, nezpracováno, návrh lhůty prodloužení k vystoupení čs. občanů ve vztahu k amnestii prezidenta republiky ze dne 22. července 1919.

26 Alespoň její dominující části.

27 Známá jsou např. slova Tomáše Garrigue Masaryka, která přednesl již jako československý prezident při své první zprávě o stavu republiky dne 22. prosince roku 1918, dle kterých: „My jsme vytvořili náš stát; tím se určuje postavení našich Němců, kteří původně přišli do naší země jako emigranti a kolonisté.“Viz KOSATÍK, P. 100x TGM. Praha: Knižní klub, 2017, s. 130.

28 Viz PICHLÍK, K. Masarykovy představy o poválečném uspořádání Evropy. In: GAJAN, K. (usp.) T. G. Masaryk a vztahy Čechů a Němců. Sborník př́spěvků pronesených od listopadu 1993 do června 1995 v rámci Masarykovy společnosti na FF UK v Praze. Praha: Masarykova společnost, 1997, s. 136 a 143.

29 Tamtéž, s. 139.

30 Ze vzpomínek dobových pamětníků viz např. HORÁČEK, c. d., s. 206.

31 Oproti obvykle použitému překladu substantiva Umfang jako rozsah mi z hlediska normativního významu přijde pojem obvod přiléhavější.

32 Viz $§ 1$ zákona č. 40/1918 StGBl.

33 Viz PICHLÍK, c. d., s. 145.

34 Viz GAJAN, K. Německý imperialismus a Československo. Československo-německé vztahy v letech 1918 - 1921. Praha: Nakladatelství Čs. Akademie věd, 1962, s. 45. 
dohodových států včetně Československa, uznal ovšem německý generální konzul Fritz von Gebsattel ${ }^{35}$ svrchovanost československého státu již 2. listopadu roku 1918. ${ }^{36}$ Místo, aby sudetoněmečtí politici, jak jim ostatně radil von Gebsattel, ${ }^{37}$ využili nejistou, a tím relativně prŕźnivou konstelaci pro pragmatický aktivismus, jenž by jim mohl přinést alespoň prríslib dalekosáhlejších ústupků, rozhodli se krátkozrace ${ }^{38}$ pro radikálnější postup, dočasně podpořeni postupem rakouského ministerstva zahraničí. ${ }^{39}$

$\mathrm{V}$ rámci tohoto postupu byly některé jednotky Volkswehru i části bývalých jednotek rakouské branné moci složené z českých Němců (podle některých údajů o síle až několika tisíc mužư ${ }^{40}$ ) staženy do zahraničí (nejen do Rakouska, ale i Německa ${ }^{41}$ ), kde se rovněž začaly vytvářet ze shora řečených sborů a dalších dobrovolníků, at’ už branci přicházeli z Československa, Rakouska, Německa nebo odjinud, tzv. Sudetoněmecké bataliony, tzn. polovojenské útvary vedené Vrchním vojenským velitelstvím pro německé Čechy, Moravu a Slezsko. ${ }^{42}$ Tyto jednotky měly ve vrcholném období cca 40000 mužů ${ }^{43}$ měly vlastní výzvědnou službu, volené důstojníky, náborovou kancelář i symboliku (rakouská dýka obrácena ostrrím dolů a překryta písmenem S). ${ }^{44}$ Tyto bataliony ovšem byly podř́zeny rakouské, resp. německé armádě a náklady na jejich údržbu hradilo Německé Rakousko. ${ }^{45}$ Zejména pod vlivem neúspěchů československých ozbrojených sil v boji proti Mad'arské republice rad (oficiální stát se označoval Mad'arská socialistická sovětská federativní republika) se bataliony aktivizovaly, občas překračovaly československé území, napadaly československé hlídky ${ }^{46}$ a připravovaly obsazení jihočeských obcí i dalších regionů. ${ }^{47}$

35 Působil do března 1919. Viz AGSTNER, R. Cizi konzuláty v Čechách, na Moravě a ve Slezsku. Praha: Ústav mezinárodních vztahů, 2008, s. 93.

36 ALEXANDER, M. Quellen zu den deutsch-tschechischen Beziehungen 1848 bis heute. Darmstadt: Wissenschaftliche Buchgesellschaft, 2005, s. 117.

37 Dokument A6 ze dne 25. ř́jna 1918: ALEXANDER, M. Deutsche Gesandtschaftsberichte aus Prag. Innenpolitik und Minderheitenprobleme in der Ersten Tschechoslowakischen Republik. Teil I. Von der Staatsgründungs bis zum ersten Kabinett Beně̌ 1918-1921. Gesandtschaftsberichte I., München: Oldenbourg, 2003, s. 560-561.

38 Názor o krátkozrakosti KUČERA, J. Minderheit im Nationalstaat. Die Sprachenfrage in den tschechisch-deutschen Beziehungen 1918-1938. München: Oldenbourg, 1999, s. 62.

39 ALEXANDER, Quellen, s. 119.

40 GAJAN, Německý imperialismus, s. 90.

41 Např. Zemské velitelství pro Čechy hlásilo, že takové jednotky jsou budovány u Drážd’an. Viz Tamtéž, s. 92. Spolehlivé údaje měla též zemská vláda slezská, kdy centrum v Nise mělo 8000 mužů Sudetských batalionů. Viz Vojenský historický archiv, Ministerstvo národní obrany - Hlavní štáb - Operační oddělení 1 1919-1939, Odbor III.2., inv. č. 136, Sign. 73/2, Zpráva zemské vlády slezské v Opavě ze dne 18. června 1919, karton 1 (226).

42 GAJAN, Německý imperialismus, s. 91.

43 Viz Tamtéž, s. 107.

44 Podle Zprávy zemské vlády slezské v Opavě ze dne 18. června 1919. Viz Vojenský historický archiv, Ministerstvo národní obrany - Hlavní štáb - Operační oddělení 1 1919-1939, Odbor III.2., inv. č. 136, Sign. 73/2, Napjatá situace ve Slezsku, rozložení tzv. „Sudetenbatalionů“, karton 1 (226).

45 Viz Tamtéž.

46 Např. Zpráva zemského velitelství v Brně ze dne 31. března 1919 hlásila ministerstvu zahraničních věcí, že v noci ze dne 29. na 30. března došlo k přepadení stráže a únosu tří vojáků u Vidnavy. Viz Vojenský historický archiv, Ministerstvo národní obrany - Hlavní štáb - Operační oddělení 1 1919-1939, Odbor III/2, inv. č. 83, Sign. 73/3, Přepadení čs. stráže u Vidnavy oddílem „Volkswehru“, karton 1 (357).

47 Podle zprávy dr. Fiedlera, diplomatického zástupce ČSR ve Vídni ze dne 27. listopadu roku 1918. Viz GAJAN, Německý imperialismus, s. 42. Též např. ze Strakonic přišla přes Zemské velitelství v Praze zprá- 
Situace se ovšem významně změnila po uzavření Saint Germainské mírové smlouvy dne 10. záŕí 1919, byt' tato mezinárodní smlouva vstoupila v účinnost až o půl roku později, dne 16. července 1920. ${ }^{48}$ Tehdy došlo k rozpuštění Sudetských batalionů, a otázka, co s jejich bývalými členy, byla ožehavou jak pro československou, tak pro rakouskou, resp. německou stranu. Přestože se jednalo o osoby, které bojovaly proti zájmům Československa, z důvodu snížení počtu ozbrojených oponentů a uklidnění situace přistoupila nakonec československá politická reprezentace k vyhlášení amnestie dne 22. července roku 1919.49 Nadto bylo možné zařadit, byt' původně rivalizující až nepřátelské, důstojnické kádry do řad vznikající československé armády. K tomu také docházelo, byt' nikoliv automaticky, ale na základě žádosti zájemce a následného rozhodnutí Osobní a stížnostní komise. ${ }^{50}$ Tento přístup ostatně nebyl ojedinělý. Objevoval se i v zahraničí, v nově vznikajících státech nebo tam, kde probíhala občanská válka. ${ }^{51}$

Osnova amnestie byla připravena ministerstvem národní obrany. ${ }^{52}$ Ministerstvo rovněž vydalo prováděcí výnos MNO č. j. 4648 k amnestijnímu rozhodnutí, kde bylo zdůrazněno, že je zaručena beztrestnost všem osobám, jež vstoupily do německých nebo rakouských ozbrojených formací, a to i těm, jež sloužily pohraniční službu. ${ }^{53}$ Amnestie se ovšem vztáhla v rámci již zmíněného prodloužení její účinnosti ke dni 14. února roku $1920^{54}$ i na osoby, jež sloužily v pobaltských německých oddílech, které vedly občanskou válku jak proti jednotkám Rudé armády, tak proti lotyšským nacionalistům. V nich sloužilo asi 5000 osob s domovským právem na území Československa. Právě jejich deputace si vymohla prodloužení lhůty účinnosti amnestie. ${ }^{55}$

va, že se na hranicích připravují prapory Deutschböhmen v síle 8000-10 000 mužů, které se chystají k útoku na Svitavy (Vimperk, Volary a Prachatice), přičemž počítají s podporou ze strany některých místních, kteří už v listopadu 1918 strhávali telefonní a telegrafní spojení. Viz Vojenský historický archiv, Ministerstvo národní obrany - Hlavní štáb - Operační oddělení 1 1919-1939, Odbor III/2, inv. č. 131, Situační zpráva z jižních Čech, soustředění praporů př́islušníků Deutschböhmen, karton 1.

48 Podrobněji viz DEJMEK, J. a kol. Zrod nové Evropy. Versailles, St.-Germain, Trianon a dotvářeni poválečného mírového systému. Praha: Historický ústav AV ČR, 2011.

49 Viz Archiv Kanceláře prezidenta republiky, KPR, Protokol P, sign. P III 1013/22, nezpracováno, rozhodnutí prezidenta republiky ze dne 22. července 1919.

50 GAJAN, Německý imperialismus, s. 121.

51 Připomenout lze např. sovětský amnestijní dekret z roku 1920, obsahující agraciaci jakýchkoliv protiprávních činů všech bělogvardějských důstojníků, pokud tito vstoupili do Rudé armády v době polsko-sovětské války. Viz LITERA, B. Rudá armáda a problém loajality za občanské války v Rusku. Moderní dějiny, 2011, roč. 19, č. 2. Praha: Historický ústav AV ČR, 2011, s. 58. Srov. též LENIN, V. Sebrané spisy. Sv. 37. Praha: Svoboda, 1988, s. 261.

52 Viz VHA, Vojenská kancelář prezidenta republiky I. 1919-1939, Všeobecná registratura, č. j. 950, karton 12, Všeobecná amnestie za vstoupení do německé nebo rakouské armády.

53 GAJAN, Německý imperialismus, s. 119.

54 Koloman Gajan uvedl, že byla ke dni 14. února 1920 vyhlášena nová amnestie. Viz Tamtéž, s. 123. Přitom se však stále jednalo o účinnost amnestijního rozhodnutí ze dne 22. července 1919, jak ukazují archiválie z AKPR.

55 Viz Archiv Kanceláře prezidenta republiky, KPR, Protokol P, sign. P III 1013/22, nezpracováno, rozhodnutí prezidenta republiky ze dne 22. července 1919. 


\section{Amnestie dotýkající se národnostních menšin v letech 1920-193856}

Amnestie, týkající se národnostních menšin, měly povětšinou charakter agraciace trestů (obvykle nikoliv dalších právních účinků) dotýkajících se tzv. politických deliktů, resp. abolice řízení o nich.

Politické delikty lze definovat jednak podle formálního kritéria, tj. jejich zařazení v systematice trestněprávních kodexů, jakožto zločinů proti státu či proti státní bezpečnosti, zahrnujících zvláště vzpouru, velezradu a rozvracení státu. ${ }^{57} \mathrm{~V}$ Československu by se takovým formálním kritériem staly zákon č. 117/1852 ř. z., o zločinech, přečinech a přestupcích, zákonný článek č. V/1878, o zločinech a přečinech ${ }^{58}$ a především zákon č. 50/1923 Sb. z. a n., na ochranu republiky. V řízení o nich pak lze při uplatnění komparativní metody př̌i sledování aplikační praxe vysledovat některé společné znaky, které lze při vymezení jednání spadajících mezi tyto delikty rovněž použít, jako je délka procesů, intervence subjektů trestního řízení, ${ }^{59}$ dodržení práva na spravedlivý proces, jejich mediální a politický obraz a charakter, příp. eventuální rízení vůči př́islušníkům názorové nebo národnostní skupiny. ${ }^{60}$

Vedle shora uvedeného užšího pojetí, vycházejícího spíše z přístupu opírajícího se o formální elementy, lze však vymezit politické delikty a procesy o nich ještě jinak, a to jako jednání, kdy „lidé, kteří se určitými názory či přesvědčením neshodují s panující politikou státu, jsou za jednání, jež jsou projevem takových názorů či přesvědčení ve vnějším světě, trestně sankcionováni““.61 Toto pojetí umožňuje zdůraznit definiční znaky konkrétního jednání naplňujícího znaky různých trestných činů, jež vnímáme jako politické, a odlišit je právě od činů, u nichž onen „politický“ prvek absentuje. Definice přitom vychází z dobové právní praxe. Někdy byly vymezeny výčtem konkrétních ustanovení právních předpisů př́mo $\mathrm{v}$ amnestijním aktu, ale toto bylo nejednotné. Vzhledem ke skutečnosti, že rámec politických deliktů byl sám o sobě ze své povahy dost neurčitý i pro tehdejší normotvorbu, jurisprudenci i aplikační praxi, ${ }^{62}$ a určení toho, zda se jedná o politický

56 Následující pasáž vychází zčásti z článku ŠOUŠA, c. d., s. 42-68.

57 Viz ČERNEVIČIŪTĖ, S. Politiniu nusikaltimu samprata Lietuvoje 1919-1940 m. [The Concept of Political Crimes in Lithuania, 1919-1940]. Teise [Law]. 2016, No. 99. Vilniaus, s. 154 a 173.

58 K ochraně státu na území dnešního Slovenska v meziválečném období z poslední doby viz např. ILLÝOVÁ, Z. Trestnoprávna ochrana Československej republiky (1918-1938). In: VOJÁČEK, L. - TAUCHEN, J. III. česko-slovenské právně historické setkání doktorandi̊ a postdoktorandů. Sbornik z konference. 1. vyd. Brno: Masarykova univerzita, Právnická fakulta, 2015, s. 89-99.

59 K vymezení subjektů trestního řízení viz např. CíSAŘOVÁ, D. - FENYK, J. a kol. Trestní právo procesní. 3. aktualizované a rozšířené vydání. Praha: Linde Praha a.s., 2004, s. 84-85.

60 Tato komparativní kritéria vytýčil ve své diplomové práci Suchomel. Viz SUCHOMEL, c. d., s. 8. Kritéria jsou zpracována poměrně kvalitně, viz SUCHOMEL, $c . d$., s. 72-80. Jde ovšem jen o príkladovou práci. Některé analytické závěry by si nadto zasloužily dále dopracovat. Např. výše trestu není pro dodržení práva na spravedlivý proces významná, neb se nejedná o procesní, nýbrž primárně o hmotněprávní otázku. Odlišně SUCHOMEL, $c$. $d$., s. 75. Výjimku podle platného práva, kdy se právo na soudní a jinou ochranu dotýká trestu, představuje dnes článek 39 Listiny základních práv a svobod, podle kterého by bylo porušením práva na soudní a jinou ochranu ovšem jen uložení trestu, který předpis nezná nebo v nepřiměřeném rozsahu.

61 Viz ŠOUŠA, $c . d$. s. 43.

62 Př́klady politických deliktů lze vyčíst např. z dokumentů k politické amnestii ze dne 13. února 1922 a k hromadným milostem politických i nepolitických delikventů v: Národní archiv, Ministerstvo spravedlnosti Praha 1918-1953, inv. č. 697, sig. VI 1/5, karton 978, návrh na udělení milosti účastníkům generální stávky. 
delikt, bylo komplikovanější, snažil se ho vymezit článek 3 výnosu ministra spravedlnosti č. 33030/19 ze dne 10. května roku 1920. ${ }^{63}$ Podle něj bylo nutné posuzovat každý případ zvlášt', přičemž za pomocné kritérium, jaké jednání je politickým trestným činem, na nějž se vztahuje amnestie, mohlo sloužit hledisko výkonu trestu odnětí svobody. Politickými delikty podle tohoto kritéria byly činy, kde byla odsouzeným osobám poskytována řada úlev při výkonu trestu. Výslovně přitom výnos jmenoval urážku hlavy státu.

Politické delikty pak můžeme s ohledem na shora uvedený výnos i na amnestijní praxi ještě rozlišit na a) politické delikty v užším slova smyslu, které směřovaly výhradně vůči státu, jeho ideovým pilírumu, politickému uspořádání, teritoriální jednotě a ústavním orgánům, a b) delikty politické povahy čili trestné činy z politických pohnutek, ${ }^{64}$ tj. zločiny, přečiny a přestupky zasahující i do trestním právem běžně chráněných zájmů jako je stát, jeho forma, život a zdraví obyvatel, majetek, hospodářství apod., ale spojené s projevem myšlenkového přesvědčení pachatele, který je případně stíhán primárně právě z důvodů ochrany establishmentu. Zda se amnestují politické delikty či rovněž delikty z politických pohnutek, vyplývalo z formulace konkrétní amnestie. U amnestie politických deliktů v užším slova smyslu se sice posuzovala pohnutka také, ovšem nebyla pro zařazení deliktu do amnestované množiny určující, naopak byla snaha hledat nějaké objektivnější kritérium. ${ }^{65}$

Amnestijní rozhodnutí vyhlášená v 20. a 30. letech minulého století v Československu a mající dopady pro otázku právní úpravy národnostních menšin lze kategorizovat časově a obsahově v zásadě na čtyři množiny.

1. Prvotní, z hlediska chronologického jakousi nultou, skupinou byly již řečené amnestie z let 1918-1920, které zahrnovaly jednak „nápravné amnestie“ve prospěch příslušníků českého a slovenského národa, jednak amnestie, které jako zvláštní důvod zániku trestní odpovědnosti liberovaly příslušníky především německé menšiny, kteří i po vzniku společného státu sloužili v cizích (v zásadě nepřátelských) ozbrojených silách.

2. Následovala první množina z tohoto období, která do jisté míry navázala na druhou z již uvedených typů amnestií. Tak jako u rozhodnutí o amnestování osob sloužících $\mathrm{v}$ rakouských a řŕšskoněmeckých formacích bylo jejich bezprostřední příčinou uzavření Saint Germainské mírové smlouvy, která vlastně odstranila smysluplnost počínání adresátů amnestie, jednalo se i v tomto př́ípadě amnestijních aktů z let 1920-1938 o amnestie, související s uzavřením mezinárodních smluv se sousedními státy, s nimiž měla Československá republika územní spory (tzv. trianonská amnestie ze 7. záŕí 1922 týkající se Mad'arů a promad'arských Rusínů a plebiscitní amnestie ze dne 14. července 1925 vztahující se primárně na československé občany polské národnosti). ${ }^{66}$ Tyto amnestie byly ovšem, na rozdíl od té předchozí skupiny, nejen pouhým logickým vyús-

\footnotetext{
63 Viz KALLAB, J. - HERRNRITT, V. Trestní řád československý a předpisy jej doplňujicí platné v Čechách a v zemi moravskoslezské. 2. přepracov. a rozmnožené vydání. Praha: Čs. Kompas, 1931, s. 834.

64 Viz např. amnestie ze dne 27. května 1920, dostupná v Archiv KPR, fond KPR, Protokol D, inv. č. 1039, sign. D 12840/38, karton 136, Opis k čís. P 622/20.

65 Viz Tamtéž, s. 835.

66 Srov. PAVLÍČEK, $c$. $d$.
} 
těním mezinárodního vývoje, ${ }^{67}$ ale přímo vyplývaly z pramenů mezinárodního práva veřejného. Potvrzují tedy, mimo jiné, již zmíněnou neúplnost dualismu mezinárodního a vnitrostátního práva.

3. Do druhé skupiny lze zařadit amnestijní rozhodnutí z let 1920-1938, které můžeme z hlediska jejich územní a místní působnosti charakterizovat jako regionálně specializované amnestie. Měly totiž teritoriálně omezenou působnost týkající se zejména Rusínů a Slováků. Přestože z pohledu tehdejší státotvorné a právní koncepce se jednalo o součást politického národa československého, ${ }^{68}$ vyvinuly se zde postupně vlivné politické elity stavějící se proti novému státu nestátotvorně. Také s ohledem na následující historický vývoj jsou proto do této množiny zařazeny i amnestie týkající se Slovenska. Amnestie dotýkající se Rusínů byla napřr. amnestie ze dne 2. prosince 1920, vztahující se jen na území Podkarpatské Rusi. Tato amnestie měla i další charakteristický rys. Týkala se totiž pouze bagatelních kriminálních delikti̊. Podobnou současně bagatelní a zároveň územně regionálně, resp. lokálně ohraničenou povahu mělo i rozhodnutí prezidenta republiky č. P 869/21 ze dne 18. července 1921, kterým prezident republiky na návrh ministra spravedlnosti učiněný v souhlasu s ministerstvem financí prominul občanům Hlučínska tresty uložené před 4. únorem 1920 za důchodkové trestné činy konšelským soudem v Hlučíně a nadřízenými soudy, at' již německými anebo československými. ${ }^{69}$ Tato regionální amnestie se týkala nacionální menšiny (konkrétně německé) jen zčásti, protože většina obyvatel části Hlučínska, jež připadlo k Československu, a tedy subjektů, na něž se amnestie vztahovala především, se před rokem 1920 hlásila k jazyku moravskému. ${ }^{70}$

4. Nejpočetněji byly př́islušníci národnostních menšin dotčení třetí skupinou amnestií, totiž amnestijními akty z 30 . let 20 . století (k nim viz dále v textu).

5. Konečně chronologicky lze do 30. let 20. století mezi amnestijní rozhodnutí vztahující se k otázce národnostní zařadit i pomnichovské amnestie z období budování autoritativního státu. ${ }^{71}$ Jejich mezinárodněprávním podkladem byla dohoda čtyř velmocí v Mnichově - Dohoda mezi Německem, Spojeným královstvím, Francií a Itálií, onen v noci ze dne 29. na 30. září 1938 dojednaný pakt, známý spíše pod názvem: Mnichov-

67 Přesněji řečeno logickým vyústěním vzhledem k humanitně demokratickému charakteru první Československé republiky.

68 S tímto teoretickým konstruktem operoval Tomáš Garrigue Masaryk ve svých spisech, viz např. MASARYK, T. G. Nová Evropa. Stanovisko slovanské. 5. vydání. Praha: Ústav T. G. Masaryka, 2016, ale najdeme ho např. zprostředkovaně odkazem na československý jazyk i v § 131 Ústavní listiny 1920 nebo v ústavním zákoně č. 122/1920 Sb. z. a n., jímž se stanoví zásady jazykového práva v republice Československé.

69 NA, fond 1082 Předsednictvo ministerské rady 1918-1945, inv. č. 2170, sign. 157/3, karton 1587, Prominutí následků odsouzení pro důchodkový přestupek milostí prezidenta republiky.

70 Viz MYŠKA, M. Zápas Čechů o Hlučínsko (Před rokem 1920). In: Evropa mezi Německem a Ruskem. Sbornik praci k sedmdesátinám Jaroslava Valenty. Praha: Historický ústav AVČR, 2000, s. 263.

71 Charakteristiky režimu tzv. 2. Československé republiky se mohou různit. Přidržuji se zde konstruktu Jana Rataje, který lze z právního hlediska považovat za zcela seriózní. Viz RATAJ, J. O autoritativní národni stát. Ideologické proměny české politiky v druhé republice 1938-1939. Praha: Karolinum, 1997. Obdobně kriticky se na úlohu pomnichovské republiky díval např. významný národně demokratický politik Vlastimil Klíma, náležející do okruhu politické skupiny Ladislava Rašína. Viz KLÍMA, V. Druhý odboj (1939-1945). Svědectví a úvahy. Praha: Masarykův ústav a Archiv AV ČR, v.v.i. a Nakladatelství Lidové noviny, 2017, s. 43-44 a 55. 
ský diktát. Jeho článek $8^{72}$ totiž zakotvoval vyslovený závazek pro Československo, konkrétně pro jeho vládu, omilostnit do čtyř týdnů ode dne uzavření dohody všechny české Němce, jež byli postiženi v souvislosti s mnichovskými událostmi, jednajíce ve prospěch (resp. v neprospěch) některého z jejich aktérů. Systematicky ovšem do tohoto článku již nepatří, nebot' jde již o obecně závazné normativní akty spadající do doby nesvobody. ${ }^{73}$ Ze stejného důvodu nejsou proto také součástí právního řádu. ${ }^{74}$ To ostatně potvrzuje i právní praxe, ${ }^{75} \mathrm{kdy}$ podle čl. 6 odst. 4 a 5 zákona č. 12/1946 Sb., jímž se schvalují, doplňují a mění předpisy o obnovení právního pořádku, ${ }^{76}$ bylo na návrh veřejné obžaloby usnesením příslušného soudu zrušeno usnesení soudu o prominutí trestu nebo zastavení trestního stíhání s ohledem na amnestii a vydány na dotyčné osoby zatykače.

Přestože menšinová problematika rezonuje v amnestiích již od prvních svobodných, všeobecných, rovných a prímých voleb, konaných podle proporcionálního systému, právě amnestie spadající do čtvrté, shora vymezené skupiny, byly s menšinovou problematikou spojeny (alespoň co se počtu recipientů týče) nejvýrazněji, protože také politických deliktů a zvláště deliktů z politických pohnutek bylo př́slušníky národnostních menšin spácháno a posléze souzeno a trestáno mnohem více, a to zvláště stoupenci Adolfa Hitlera, aktivně podněcovanými ze strany Německé říše. Už v roce 1933 německý vyslanec Walter Koch ${ }^{77}$ referoval ve své zprávě o tom, že v důsledku stále výraznější inklinace německých obyvatel k nacionálnímu socialismu dochází k ostřejšímu postupu proti opozici (německé, mad'arské a komunistické) ze strany československých úřadů. ${ }^{78} \mathrm{Z}$ některých provedených statistických výzkumů zatím ovšem vyplývá, že bodem zlomu byl rok 1935, kdy s růstem aktivit nacionálně orientovaných německých organizací a uzavřením smlouvy Československa se Svazem sovětských socialistických republik se pozornost obrátila od komunistů směrem k německé nacistické iredentě. Č́stečný časový posun od nástupu Hitlera k moci je i logický, nebot' nacistická vláda potřebovala nějaký čas pro dokončení kroků k mocenskému posílení své vlády. ${ }^{79}$

Nárůst trestných prrípadů ve druhé polovině 30. let 20. století v Československu souvisejících s menšinami odráží kupříkladu statistiky rozsudků Krajského soudu v Brně podle zákona č. 50/1923 Sb. z a n., na ochranu republiky. Podle nich zatímco ještě v roce 1934 připadalo $52 \%$ z celkového počtu souzených věcí na tzv. „komunistické“ delikty,

\footnotetext{
72 Viz fotokopie Mnichovské dohody z Politisches Archiv. Auswärtiges Amt v digitalizované podobě dostupný dne 5. 8. 2017 na https://jirikkucera.files.wordpress.com/2011/03/mc3bcnchner-abkommen1.pdf.

73 Období od 30. záŕi 1938 do 4. května 1945.

74 Viz čl. 1 odst. 2 ústavního dekretu č. 11/1944 Úř. věst. čsl., o obnovení právního pořádku. Srov. PAVLÍČEK, c. d., s. 181 .

75 Viz např. případ št. kapitána V. K. v VHA, Divizní soud Praha 1918-1938, inv. č. 1129, Dtr 499/36, karton 143

76 Př́lohou zákona byl právě ústavní dekret č. 11/1944 Úřr. věst. čsl.

77 Byl vyslancem od roku 1921 do roku 1936. Viz údaj dostupný dne 2. 2. 2018 na http://forum.valka.cz/topic /view/26941/Sefove-diplomatickych-misi-28-10-1918-25-2-1948.

78 ALEXANDER, Quellen, s. 162.

79 Tyto kroky spočívaly mj. v Lipském procesu, jehož rozsudek byl ve Spolkové republice Německo zrušen až v roce 2008 , nebo v Noci dlouhých nožů ad.
} 
v roce 1935 to bylo $39 \%$ a v roce 1936 již pouhých $8 \%{ }^{80}$ Naproti tomu výrazně ve stejném období narostly trestné činy „fašistické“" 81 a delikty proti státnímu zřízení. Ty predstavovaly v roce $193436 \%$, resp. $5 \%$, v roce $193537 \%$, resp. $23 \%$ a v roce 1936 již $36 \%$, resp. $25 \%$, přičemž se k nim ovšem v rozsahu $28 \%$ přidaly delikty proti bezpečnosti a obraně státu, ${ }^{82}$ které páchali povětšinou rovněž př́slušníci nacionálních menšin. ${ }^{83}$

Zároveň však v rámci trestní politiky byla tvrdost uvedených rozsudků, dotýkajících se v nemalé míře příslušníků národnostních menšin, zmírněna v letech 1935-1938 vyhlášenými amnestiemi. A to přesto, že amnestie by měly, když už uznáme tento jejich účel, ${ }^{84}$ napravovat důsledky nedokonalosti trestních zákonů, ne tolik tvrdost soudních rozsudků, pokud jsou tyto neexcesivní, nejde o přehmaty, ale o uplatnění trestního zákona, nepřekračujícího tolerovatelnou míru nespravedlnosti. ${ }^{85}$ Srovnáme-li četnost amnestií, vyhlášených československou hlavou státu od roku 1935 do 30. záŕí roku 1938, které byly za necelé tři roky celkem tři (14. prosince roku 1935, 6. března roku 1937 a 16. dubna roku 1938) nelze nevnímat vliv rychle plynoucí doby a na sebe se vršících událostí mezinárodní i vnitrostátní evoluce. Souvislost s menšinovou otázkou a zároveň převahu deliktů politické povahy směřujících proti důležitým státním zájmům - státnímu zřízení, bezpečnosti a obraně státu (nikoliv politických, jen názorových deliktů) - potvrzují i vedle shora uvedených statistik judikatorních zde i statistiky amnestijní. Např́klad amnestie z dubna 1938 se dle statistických údajů ministerstva spravedlnosti ${ }^{86}$ týkala celkem 3.550 osob, čtvrtina všech zločinů připadala na delikt vojenské zrady, ${ }^{87}$ u přečinů bylo nejpočetnější rušení obecného míru. ${ }^{88} \mathrm{Z}$ národnostního hlediska tvořili z celkového počtu amnestovaných $42 \%$ př́slušníci českých Němců.

V období 1935-1938 docházelo v rámci amnestií také k zvyšování benevolence vůči povaze spáchané trestné činnosti. Poslední z amnestií politických deliktů prezidenta Masaryka, týkající se zároveň menšin, byla amnestie ze dne 14. prosince roku 1935. Měla přispět k uklidnění situace v republice. ${ }^{89}$ Byla čistě politická a zároveň svou osobní a věcnou působností poměrně úzká. Vztahovala se na méně závažné politické delikty - jednak přečiny a přestupky urážky prezidenta ${ }^{90}$ nebo další delikty dle zákona č. 50/1923 Sb. z. a n., na ochranu republiky, spáchané v souvislosti s volbou Edvarda Beneše prezidentem republiky, a ,netýkala se těch deliktů, kde byl spolu s politickým deliktem spáchán ,běžný‘ byt’ sebebagatelnější trestný čin anebo pokud šlo o násilí proti úřední osobě, i kdyby důvody takového násilí (např. napadení exekutora) měly svůj původ v těžké sociální situaci

80 Viz HORÁKOVÁ, M. Odraz totalitní skutečnosti v československém zákonodárství 30. let 20. století. Brno, 2013. Disertační práce. Masarykova univerzita v Brně, s. 68-70. Autorka provedla statistiku dle dat dle dat v Moravském zemském archivu, fond Krajský soud trestní Brno C12.

81 Kam se zahrnovala i propagace a činnost nacionalistických českoněmeckých stran, spolků a hnutí.

82 Zahrnující většinou špionáž a vyzrazení informací Německu a Polsku. Viz HORÁKOVÁ, c. d., s. 70.

83 Viz HORÁKOVÁ, c. d., s. 68-70.

84 Právní řád má totiž dostatek prostředků pro zohlednění celkové situace pachatele v konkrétním případě. Viz KANTOŘÍKOVÁ, J. K otázce prezidentských milostí. Právní fórum, roč. 1. č. 1. Praha, s. 32.

85 PAVLÍČEK, c. d., s. 176.

86 ŠOUŠA, c. d., s. 66.

87 § 6 zákona č. 50/1923 Sb. z. a n.

$88 § 14$ a 14a zákona č. 50/1923 Sb. z. a n.

89 NA, Ministerstvo unifikací 1919-1938, inv. č. 281, sign. III/4/1, karton 22, Politická amnestie, ministerské vyjádření 1937.

$90 \quad$ Dle $\S 11$ zákona č. 50/1923 Sb. z. a n. 
útočníka. Rovněž se netýkala případů, kdy se viník jiného deliktu, než urážky prezidenta republiky vyhýbal trestnímu stíhání anebo vstoupil za účelem spáchání jinak amnestovaného trestného činu do styku s cizí mocí, zejména s vojenskými a finančními činiteli.“91

Abolice podle tohoto amnestijního rozhodnutí se týkala a) trestních přestupků proti zákonům o právu spolkovém a shromažd'ovacím, ${ }^{92}$ b) přestupků ..., ${ }^{93} \mathrm{c}$ ) přestupků rušení obecného míru, např. pobuřování proti státu a ..., ${ }^{94} \mathrm{~d}$ ) přečinu ..., ${ }^{95} \mathrm{~s}$ výjimkou založení, členství, podpory, neoznámení nebo nepřekažení tajné zahraniční organizace, e) přečinů ..., ${ }^{96} \mathrm{~s}$ výjimkou odstranění, poškození státního znaku a symbolu, f) vybraných tiskových deliktů. ${ }^{97}$ Agraciace u těchto deliktů byla omezena tříměsíční délkou trestu odnětí svobody. Abolice i agraciace se vztahovaly rovněž na peněžité tresty a podmíněná odsouzení.

Věcné zúžení této amnestie se projevilo rovněž na personální působnosti amnestijního rozhodnutí. Podle Memoranda panu presidentu republiky o nutnosti nové amnestie, vytvořeného občanským spolkem označujícím se Sdružení na obranu práv a pro sociální pomoc, se dobrodiní amnestie dotklo jen 1700 osob z celkového počtu 16916 prŕpadů politických věznù. ${ }^{98}$

Oficiální počty se od uvedených čísel občanského spolku odlišovala. Podle statistik ministerstva spravedlnosti se amnestijní rozhodnutí z roku 1935 dotklo cca 10000 provinilců, z toho se asi polovina týkala tiskových deliktů a zbytek byly delikty ${ }^{99}$ politické a obdobné. Téměř trojnásobný rozdíl mezi 1700 a 5000 recipienty amnestijních norem může spočívat v odlišném definičním vymezení politických deliktů. Lze předpokládat, že oficiální čísla vycházela spíše z formální definice soudní a týkala se snad i osob, u nichž naopak Sdružení na obranu práv a pro sociální pomoc akcentovalo ještě další, kriminální stránku věci, a na druhou stranu mezi sankce za politické delikty počítalo i další právní následky odsouzení. Svou roli mohla sehrát i skutečnost, že sdružení reprezentovalo spíše levou část politického spektra a nemělo dostatek informací o dopadech na německé, mad'arské, polské nebo české nacionalisty.

Na předchozí amnestii navázala amnestie ze dne 6. března roku 1937, kterou již vyhlašoval prezident Edvard Beneš. Text amnestie připravilo ministerstvo spravedlnosti a předloha byla projednána ve vládě dne 5. března roku 1937. Vycházela ze stejných premis a koncepcí jako předchozí rozhodnutí, byla ovšem širší, například se na rozdíl od předešlé vztahovala i na zločiny, jakožto nejzávažnější druh trestněprávních deliktů. ${ }^{100}$

Právě tuto šíri kritizoval na jednání např̀. ministr unifikací J. Šrámek, který měl připomínky k tomu, aby byla dávána aktivistům Sudetoněmecké strany, nebot’ jejich činy byly,

\footnotetext{
$91 \quad$ ŠOUŠA, $c$. d., s. 64.

92 Zákon č. 134/1867 ř. z. a č. 135/1867 ř. z.

93 § 4 a 5 zákona č. 309/1921 Sb. z. a n., proti útisku a na ochranu svobody ve shromážděních.

$94 \S 14$ a 18 zákona č. 50/1923 Sb. z. a n.

$95 \$ 17$ zákona č. $50 / 1923$ Sb. z. a n.

$96 \$ 20$ zákona č. 50/1923 Sb.z. a n.

97 Viz čl. II. odst. 2 rozhodnutí prezidenta republiky ze dne 14. prosince 1935.

98 Memorandum panu presidentu republiky o nutnosti nové amnestie. Praha: Solidarita. Sdružení na obranu práv a pro sociální pomoc, 1936.

99 NA, Ministerstvo unifikací 1919-1938, inv. č. 281, sign. III/4/1, karton 22, Záznam dne 5. března 1937.

100 NA, Ministerstvo unifikací 1919-1938, inv. č. 281, sign. III/4/1, karton 22, Politická amnestie. Viz též AKPR, KPR, Protokol D, inv. č. 1039, sign. D 12840/38, karton 136, Opis k čís. P -327/37.
} 
alespoň podle statistických údajů, stíhány méně intenzivně, než se tomu dělo do poloviny 30. let, což bylo do jisté míry paradoxní, když naopak tyto činy ohrožovaly samu podstatu existence republiky. Šrámek se rovněž negativně díval na skutečnost, aby se amnestie týkala činů spáchaných nedávno, protože to podle jeho názoru jen podpoří „chut’ k opakování trestných činů, o něž tu jde“". ${ }^{101}$

Amnestie z roku 1937 spočívala jak v agraciaci, tak v abolici, rozlišovala při nich politické delikty do dvou skupin. ${ }^{102}$ A) První skupinu tvořily přečiny a přestupky proti zákonu na ochranu republiky a dalším právním předpisům (zákony spolčovací, ${ }^{103}$ shromažd'ovací, ${ }^{104}$ tiskové ${ }^{105}$ ) a útisk proti svobodnému konání shromáždění, ${ }^{106}$ kdy tyto delikty páchali v dané době zejména stoupenci Sudetoněmecké strany. U těchto deliktů právní účinky prominutí trestů i zastavení trestního stíhání nastávaly přímo dnem vyhlášení amnestie. B) Druhou skupinu tvořily zločiny podle zákona na ochranu republiky s výjimkou zločinu vojenské zrady, podněcování k vojenským zločinům a dalších zločinů namířených proti branné moci, a dále zločiny a přečiny, které byly spáchány v souběhu s delikty nepolitickými, u nichž ovšem pohnutka nebyla nečestná anebo jejichž pachatel se zdržuje v cizině. Ministerstvo spravedlnosti, jež návrh amnestie vypracovalo, mělo na mysli v tomto ohledu amnestovat např. násilí proti úředním orgánům a osobám, které bylo spácháno pod tlakem těžkých hospodářských a sociálních poměrů, zejména při výkonu exekucí (např. události při daňové exekuci v Čertizném) anebo v průběhu pracovních a mzdových sporů. Podle odůvodnění zlepšující se hospodářské poměry po přestálé krizi již umožňovaly amnestii, protože nehrozilo, že by mírnost v postihu takového jednání podnítila větší rozmach těchto deliktů. ${ }^{107}$ „Podle statistik ${ }^{108}$ se abolice dle zákona na ochranu republiky týkala celkem 1635 osob (z toho 623 sudetských Němců) a agraciace 897 osob (z toho 413 prŕvrženců Sudetoněmecké strany)." ${ }^{109}$

K provedení této amnestie vydalo ministerstvo spravedlnosti výnos ze dne 11 . března 1937, č. j. 13.258/37/16, č. 4 Věstníku ministerstva spravedlnosti. V něm se mimo jiné uvádělo, že podání žádosti o udělení milosti v př́padě hromadných milostí nemůže být důvodem pro povolení odkladu nástupu trestu, protože podle článku III. amnestijního rozhodnutí, tj. u hromadné amnestie, se postupovalo podle trestních řádů, ${ }^{110}$ které umožňovaly přerušení či odklad výkonu trestu jen na základě rozhodnutí prezidenta republiky, ministra spravedlnosti, Nejvyššího nebo vrchního soudu nebo vrchního státního zastupitelství, ${ }^{11}$ což soudy v praxi dodržovaly. Skutečnost, že museli odsouzení nastoupit výkon trestu

101 Viz Národní archiv - 904 Ministerstvo unifikací 1919-1938, č. inventáře 465, inv. č. 281, sign. III/4/1, karton 22, Záznam dne 5. března 1937.

102 NA, Ministerstvo unifikací 1919-1938, inv. č. 281, sign. III/4/1, karton 22, Záznam dne 5. března 1937.

103 Zákon č. 134/1867 ř. z.

104 Zákon č. 135/1867 ř. z.

105 Zákony č. 126/1933 Sb. z. a n., č. 140/1934 Sb. z. a n. a č. 6/1863 ř. z.

106 Zákon č. 309/1921 Sb. z. a n., proti útisku a na ochranu svobody ve shromážděních.

107 NA, Ministerstvo unifikací 1919-1938, inv. č. 281, sign. III/4/1, karton 22, Politická amnestie.

108 NA, Ministerstvo unifikací 1919-1938, inv. č. 281, sign. III/4/1, karton 22, Politická amnestie.

109 ŠOUŠA, $c$. d., s. 65.

110 Jednalo se o zákon č. 119/1873 ř. z., jímž se zavádí nový řád soudu trestního (rakouský trestní ráád) a zákonný článek č. XXXIII/1896, uherský trestní řád.

111 Konkrétně $§ 411$ zákona č. 119/1873 ř. z., trestního řádu rakouského a $§ 514$ zák. článku XXXIII/1896, uherského trestního řádu. 
a teprve po uplynutí několika dní byli opět zařazeni do seznamu a propuštěni, měla výrazný výchovný dopad na psychiku odsouzených a vyvolala i na 25 . schůzi dne 27 . dubna roku 1937 interpelace v Poslanecké sněmovně Národního shromáždění, v níž byl tento postup karpatoněmeckými a sudetoněmeckými poslanci ${ }^{112}$ nesprávně, pravděpodobně v důsledku nepochopení odlišného právního režimu amnestií a hromadných milostí, označován za maření účelu amnestie. ${ }^{113}$

U již zmíněné amnestie ze dne 16. dubna roku $1938^{114}$ byl výčet amnestovaných deliktů rozšířren i na zločiny, přečiny a přestupky proti zákonu o obraně státu. ${ }^{115}$ Zvyšující se dopady pro př́islušníky národnostních menšin již byly číselně doloženy výše.

\section{III. „Problematické“" aspekty a možnosti dalšího výzkumu}

Heuristická a analytická fáze prrípravy článku o svrchu psané problematice vyjevila několik ,,problematických“ aspektů, před něž je badatel postaven, a dalších možností postupu při výzkumu této otázky. Ačkoliv, jak již bylo uvedeno v I. oddílu tohoto článku, existuje již řada publikací a statí zabývajících se historií právní úpravy postavení menšin v meziválečném období, mohou tyto, vzhledem ke specifičnosti tématu propojujícího nacionální a minoritní otázku s amnestiemi a milostmi, sloužit jen jako subsidiární a pomocný zdroj. ${ }^{116}$

První z těchto ,problematických“ aspektů tedy představuje a) materiální základna, když u pramenů o amnestiích se spíše výjimečně setkáme s tím, že by obsahovaly jednoznačné úvahy a otevřená přiznání tvưrců o jejich národnostních konotacích. ${ }^{117}$ Resp. řečené úvahy lze nalézt jen v jednotlivých dokumentech, tvořících zlomek z celkových podkladů u každé konkrétní amnestie. Některé, byt' zjevné pravdy, zůstaly prostě nevyřčeny. Obvykle tak badatel zjistí menšinový element amnestie až v průběhu rozboru zdrojových materiálů, např. analýzy ministerstva spravedlnosti při př́pravě amnestie, statistik soudních orgánů, jež aplikaci a realizaci amnestijního rozhodnutí doprovázely nebo naopak z hodnocení dopadu amnestie prováděných povětšinou ministerstvem a dalšími orgány pro prezidentskou kancelář obvykle několik měsíců po ukončení amnestie.

Dalším aspektem, který je třeba překonat a analyzovat při zpracování a zároveň jenž by si pro futuro zasloužil podrobnější analýzu, je b) různorodost forem amnestií (abolice, agraciace, rehabilitace), jejich konstruování a věcného i personálního vymezení a formulace. Důsledkem jsou výrazné dopady v jednotlivých případech recipientů ${ }^{118}$ amnestijních norem při aplikaci těchto norem. Ty se odrážejí c) mj. v různém vymezení recipientů,

112 Jedním z interpelujících byl i známý pozdější válečný zločinec Franz Karmasin. Viz k němu podrobněji např. LIPTÁK, L'. Franz Karmasin opät na scéne. Bratislava: VPL, 1962.

113 Viz tisk č. 890 Naléhavá interpelace poslance dr F. Köllnera vládě, že ministerstvo spravedlnosti zmařilo výnosem účinky amnestie. V elektronické podobě dostupná dne 10. 8. 2017 na http://www.psp.cz/eknih /1935ns/ps/tisky/t0890_00.htm.

114 Text viz AKPR, KPR, Protokol R, inv. č. 3479, sign. R 12984/38, karton 76.

115 Zákon č. 131/1936 Sb. z. a n.

116 Např. zobrazující komplexnější rámec hospodářsko-, sociálně- a politickosprávního vývoje, v němž k vyhlášení amnestií došlo a rovněž podávající přehled o tehdejší normativní úpravě menšinové věci.

117 Tak je tomu např. u tzv. mnichovských amnestií.

118 Adresátem právní normy teorie práva rozumí „subjekt, jemuž jsou adresovány příkazy, zákazy, resp. dovolení daná právní normou“. Recipientem pak „,skutečného př́jemce př́ikazu, zákazu či dovolení daného právní normou.“Viz KNAPP, V. Teorie práva. Praha: C. H. Beck, 1995, s. 70. 
v důsledku rozdílných deliktů, které byly amnestovány. Tato nezbytná individualizace při realizaci rozhodnutí o amnestii je ovšem důležitá ještě v jiném ohledu. Její absence totiž může vést dokonce $\mathrm{k}$ nesprávné výměře trestu nebo v extrémním, excesivním, př́padě, k vyřazení oprávněného jednotlivce $\mathrm{z}$ dobrodiní amnestie. Je např. důležité si uvědomit, že amnestijní rozhodnutí je důvodem zániku trestní odpovědnosti, nicméně tato fikce neznamená, že dotyčná osoba trestný čin nespáchala, takže lze k němu přihlédnout při stanovení úhrnného trestu. ${ }^{119}$

Konečně d) je vhodné upozornit, že nejsou prozatím k dispozici přesné souhrnné statistiky amnestií, jež by se dotýkaly menšinové otázky, a s nimiž by právníci mohli pracovat. Pokud nechceme suplovat úlohu hospodářských a sociálních historiků, byla by doporučeníhodná mezioborová spolupráce v tomto směru. Nejen tento, ale rovněž ostatní tři „problematické“ prvky, tedy zároveň naznačují možnosti dalšího výzkumu. Konečně je třeba poznamenat, že poznatky získané při právněhistorickém bádání nad amnestiemi, lze bezpochyby uplatnit i (nejen) v historicky komparativním duchu u současných a budoucích rozhodnutí o amnestii, at' již budou v kompetenci kteréhokoliv z ústavních orgánů.

\section{Závěr}

Shora nastíněné poznatky, jež přinesl zatímní badatelský výzkum, ukazují, že konstatování, podle něhož je otázka právní úpravy národnostních menšin (včetně jejích dílčích elementů, pozn. autora) komplikovaná, ${ }^{120}$ je zcela na místě, a současně upozorňují, jak je menšinová problematika mnohovrstevná a zasahuje do různých oblastí významněji, než se doposud soudilo. Takovou oblastí je jistě i sféra amnestijní, když amnestie lze vnímat jako institut, jenž, zejména při vpravdě kontinuálním a pravidelném uplatňování v rámci trestněprávní politiky meziválečné Československé republiky, se samotným pozitivněprávním základem hmotného a procesního trestního práva tvořil nedílný celek. V liberálním a sociálním demokratickém právním československém státě sloužil k několika účelům, $\mathrm{v}$ jedinečných případech dokonce ke zmírnění nedostatků právního systému samotného a napomáhal tak fungování trestněprávní politiky. ${ }^{121}$

Jestliže recipovaná trestněprávní úprava z doby habsburské byla, vnímáno prismatem dneška, nastavena vůči radikálnějším projevům nálad směřujících proti primárním ideovým a hodnotovým základům státu relativně přísně a „,v okamžiku, kdy se k těmto elementům přidal stát stran a menšinová problematika, kdy jednotlivé strany mohly v rámci politického boje použít různé nástroje a i vztahy menšiny a většiny nebyly ve všech fázích existence (Československa, pozn. aut.) zcela optimální a výrazně dále vzrostl aspekt možného stíhání deliktů, jež lze označit jako politické, př́ípadně delikty politické povahy“ ${ }^{122}$ nastupovaly amnestie, jakožto legitimní prostředek ${ }^{123}$ zmírňování „,nedostatků“ kodexů trestního práva, zejména za situace, kdy se zcela nepodařilo odstranit tvrdost trestněpráv-

\footnotetext{
119 Tato koncepce platí i v současnosti. V poslední době byla vyslovena např. v rozsudku Nejvyššího soudu ze dne 19. března 2014, sp. zn. 8 Tdo 1301/2013.

120 PETRÁŠ, R. Menšiny v meziválečném Československu. Právní postavení národnostních menšin v první Československé republice a jejich mezinárodněprávni ochrana. Praha: Karolinum, 2009.

121 BLÁHOVÁ, I. - BLAŽEK, L. - KUKLÍK, J. - ŠOUŠA, J. a kolektiv. Oběti komunistické spravedlnosti. Právní aspekty politických procesů 50. let 20. století. Praha: Auditorium, 2013, s. 273.

122 ŠOUŠA, $c$. d., s. 67.

123 PAVLÍČEK, $c$. d., s. 176.
} 
ních předpisů a československý stát se programově snažil udržovat proporcionalitu mezi ochranou svého demokraticko-republikánského zrrízení, ${ }^{124}$ státní a národní svrchovanosti a územní nedělitelnosti, a právě v platném právu zakotvených sankcí.

Především ale za trvání první Československé republiky jedním z jurisprudencí výslovně konstatovaných důvodů vyhlašování amnestií byla úvaha o jejich př́nosu pro uklidnění vnitropolitických poměrů a právě v takové poloze se projevovaly konotace amnestijních rozhodnutí k menšinové problematice nejvýrazněji. Je vhodné upozornit, že mezi příčiny kriminality náleží i konkrétní hodnoty sdílené společností. ${ }^{125}$ Čím méně se jedinec identifikuje se společností a s jejími deklarovanými zájmy anebo čím větší je rozpor mezi těmito navenek prohlášenými formálními hodnotami a každodenní realitou, „vznikají schizmata a odcizení a zvyšuje se nerespektování legality“. ${ }^{126}$ Příčinou kriminality tak může být ztráta identifikace s panujícím establishmentem, jež může vyústit až ve ztotožnění se s radikální opozicí vůči němu. To se stalo u nemalé části příslušníků některých národnostních menšin, které se ve druhé polovině 30. let 20. století, částečně také pod vlivem dozvuků hospodářské krize, některých nedostatků menšinové politiky, ale rovněž výrazného vměšování zahraničních totalitních či autoritářských mateřských států těchto menšin, postavily do ostré opozice vůči státu.

Vedeny humanistickou koncepcí Masarykovou, ale především také pod vlivem evoluce mezinárodní situace, začaly se př́íčiny hlavou československého státu vyhlášených amnestií téměř zcela překrývat s menšinovou otázkou, kdy značná část recipientů amnestie spadala právě mezi příslušníky některých národnostních menšin. Bádání ovšem rovněž ukazuje, že po roce 1935 se uplatňovaly amnestie v okamžiku, kdy neselhaly ani pojistky či opravné systémy trestního práva, ale amnestijní instrument začal působit primárně nikoliv jako nástroj zmírňování tvrdosti normy, nýbrž do jisté míry politický korektiv aktů aplikace práva, tj. soudních rozhodnutí o trestných činech příslušníků některých národnostních menšin, spáchaných povětšinou z politických pohnutek (nikoliv politických deliktech). Justicí uložené sankce se přitom pohybovaly spíše u dolní hranice trestní sazby. ${ }^{127}$ A to přesto, že uvedená jednání př́íslušníků některých národnostních menšin, trestná podle zákona, směřovala stále častěji a s rostoucí intenzitou nikoliv proti ideovým základům republiky, nýbrž proti její bezpečnosti a obraně státu. Takto uplatněné amnestie nejen, že neměly jejich tvůrci očekávaný účinek, nýbrž dlouhodobější následek byl spíše přesně opačný.

Zatímní analýza amnestií, vyhlášených mezi dvěma světovými válkami v Československé republice, souvisejících s národnostní problematikou tak ukazuje, že reálně nebyly v té době amnestie, jakožto podle tehdejší právně-filozofické koncepce hromadný druh milosti, ${ }^{128}$ primárně ohniskem lidství, ${ }^{129}$ nýbrž spíše ohniskem politiky sui generis.

124 Pojem používaný v čs. právním řádu pro označení hodnot, na nichž byl stát založen. Viz např. zákon č. 50/1923 Sb. z. a n.

125 MAREČKOVÁ, L. Milosti. Ohnisko lidství v trestním právu. Praha: Academia, 2007, s. 40.

126 Tamtéž, s. 40.

127 Rozdíl viz výše.

128 „Právo milosti není omezeno jen na př́pady individuelní, nýbrž obsahuje i právo amnestovati hromadně.“ Viz Zpráva ústavního výboru k ústavní listině Československé republiky, usnesené ústavním výborem podle $\S 14$. a 17. jednacího řádu. V elektronické podobě dostupná dne 5. 2. 2018 na http://www.psp.cz /eknih/1918ns/ps/tisky/t2421_03.htm. 